\title{
NÖVEKEDÉSI LASSULÁSOK ÉS A FÜGGŐ PIACGAZDASÁGOK ELMÉLETE KELET-KÖZÉP- EURÓPA ESETÉBEN - MAGYARORSZÁG GAZDASÁGI NÖVEKEDÉSE A VISEGRÁdI CSOPORT FEJLŐDÉSI ÚTJA FÉNYÉBEN
}

Economic growth slowdowns and the theory of dependent market economies in Central and Eastern Europe - Economic growth of Hungary in light of the Visegrad Group's development

\section{Sőreg Krisztina ${ }^{1}$}

\begin{abstract}
Absztrakt: Kétségtelen, hogy a rendszerváltást követően Kelet-KözépEurópa gazdaságai szignifikáns fejlődési utat jártak be, melynek során bőven akadtak gyors felzárkózási, illetve komolyabb visszaesési periódusok is. A Szovjetunió felbomlása óriási kihívás elé állította a régió országait: egy olyan környezetbe kerültek, ahol rövid idôn belül alkalmazkodniuk kellett a jóval fejlettebb, nyugati országok indukálta versenyhez, illetve az Európai Unióhoz való csatlakozás peremfeltételeinek teljesítéséhez. Joggal fogalmazhatunk úgy, hogy tágabb értelemben a kelet-közép-európai országok, szúkebben vizsgálódva pedig a V4-es csoport speciális esetet képez Európa fejlődését illetően. A kezdeti kiszolgáltatottságról, rugalmatlanságról, óriási gazdasági-társadalmi alulfejlettségrôl hirtelen meginduló növekedésifelzárkózási pályára való, relatíve rövid időszak alatt történő átállás nem kevés feszültség forrásának bizonyult. 2008-as gazdasági világválság előtt a közép-kelet-európai országcsoport a világ legdinamikusabban növekvő térségei között szerepelt: 2000-tôl 2008-ig az éves reál GDP növekedési ráta 4,6\% volt, az egy főre eső bruttó hazai termék növekedése pedig 4,8\%-ot ért el. Utóbbi paraméter négyszer gyorsabban bővült, mint Nyugat-Európában. Azonban hozzá kell tenni, hogy a közvetlen külföldi tőkebeáramlás hajtotta növekedés hosszú távon nem feltétlenül szolgálja a valódi felzárkózást
\end{abstract}

1 A szerzőről: A Soproni Egyetem Lámfalussy Sándor Közgazdaságtudományi Karán doktorjelölt. Elérhetősége: krisztina.soreg@gmail.com 
abban az esetben, amennyiben az adott ország vagy országcsoport nem fejleszt ki olyan stratégiát, amely növekedési stabilitásához járulna hozzá. A 2007-08-as válság alapvetően rávilágított arra, hogy jelen országok továbbra is igen sérülékeny gazdasággal rendelkeznek, ráadásul földrajzi értelemben is az Európai Unió perifériáján helyezkednek el, s éppen emiatt alakulhatott ki az elmúlt években tapasztalt elhúzódó recesszió. Jelen tanulmány keretében a visegrádi országok rendszerváltást követő és napjainkig tartó gazdasági növekedése és fejlődése kerül vizsgálódásunk középpontjába a külföldi mûködőtőke-befektetések alakulása szempontjából, valamint Magyarország pozíciója az ún. közepes jövedelmi csapda epizódok alatt. A felállított kutatási hipotézis szerint a régió fogyasztás alapú növekedése tovább fokozta a külső sokkoknak való kitettséget és a tartósan elhúzódó stagnálás kialakulását a 2008-2009-es gazdasági válság kialakulását követően.

Kulcsszavak: V4, fejlődés-gazdaságtan, növekedési lassulások, függő piacgazdaságok

Abstract: It is undeniable that the economic growth path of the Central Eastern European Countries has been often viewed as a special case within the European Union's development from the viewpoint of both medium as well as long term tendencies. After the dissolution of the Soviet Union, member states of the V4 Group were stricken by a severe transformation crisis, however, after 1995 large-scale FDI inflow has greatly contributed to the relatively high GDP growth rate of the region. The next massive growth stimulator was the 2004 accession to the European Union, nevertheless, the 2007-08 global economic and financial crisis has provoked a significant growth slowdown episode in frames of a prolonged recession in case of the Visegrad Four. In the present study, the issue under scrutiny is the overall economic development of the V4 countries concentrating on the period after the 1989 regime change until nowadays. As on the occasion of current presidency of the Group, our research focuses on the economic growth of Hungary. Despite the two relevant income trap episodes presented in this research, on the basis of recently published data it seems that the third largest country of the Four has overcome the crisis-driven economic turmoil and a slight convergence may be also detected towards the most developed centre states of the EU. Yet, if analysis is carried out in a longer term, different conclusions may be drawn concerning its catching-up tendency. On these grounds, it is important to examine how the V4 
cooperation could be further developed in order to stimulate member states' long-term economic growth and convergence. Besides the individual development of the four countries, the overall growth path of the Group and - in a broader perspective - the Central Eastern European Countries should be reorganized towards such factors as high quality human capital base, research and development investments and also high value added production for export. In frames of current paper, the economic growth and development of the Visegrad countries is examined with a special focus on foreign direct investments as well as Hungary's position during the socalled middle-income trap episodes. According to the main hypothesis of the research, the region's strong dependence on consumption has greatly contributed to the volatility of external shocks as well as the protracting growth slowdown that has developed following the economic crisis of 2008-2009.

Keywords: V4, development economics, growth slowdowns, dependent market economies

\section{BEVEZETÉS}

1991-ben a Csehszlovák Köztársaság, a Lengyel Köztársaság és a Magyar Köztáraság államfői a Visegrádi Nyilatkozat keretében egy olyan együttmúködést hoztak létre, melyben az európai integráció közös megvalósítását tűzték ki célul. 1993-ban pedig már négytagú lett a csoport Csehszlovákia felbomlása révén. A kooperáció elsô és legfontosabb eredményeként a négy tagországban mind a politikai rendszerváltást követő demokratizálódás, mind pedig a piacgazdasági átmenet megvalósítása zajlódhatott jóval hatékonyabb formában. 2004-ben pedig sikeresen megtörtént az Európai Unióhoz való csatlakozás is, amely az egyik legfőbb célkitűzésként jelent meg már a kezdetekkor is. A kelet-közép-európai (a továbbiakban: KKE) térség gazdasági stabilitása szintén állandó napirendi pontját képezi a V4-ek kooperációjának. Habár az elmúlt évtizedek felzárkózási folyamata valóban példaértékűnek tekinthető Európában, a négy ország fejlődési szcenáriói számos aspektusban elválaszthatók egymástól: utóbbi példaként említhetjük azon tényt, hogy csupán Szlovákiának állt módjában bevezetni az eurót 2009-ben. Ami az országok földrajzi elhelyezkedését illeti, a periférikus adottság egyben komoly előnynek is tekinthető, hiszen a kelet és nyugat közötti fekvés kereskedelmi szempontból számos lehetôséget jelent az országcsoport részére. Ezen felül az 
Unión kívül eső országokból érkező olcsó munkaerő szintén a gazdasági növekedés fenntartásának egy releváns tényezőjeként fogható fel. Azonban másfelől, a kívülről - alapesetben a fejlettebb centrumországok felől érkező sokkok és egyéb begyűrűző externáliák - igen rövid időn belül érzékeltetik negatív hatásaikat a térségben. A KKE-i, illetve szűkebb körben a V4 csoport legfőbb előnyei közül az alábbiakat emelhetjük ki: magasan képzett és olcsó munkaerő, alapvetően - válságmentes periódusok során - stabil makrogazdasági környezet, kedvező befektetési környezet, illetve e bekezdésben már kiemelt stratégiai jellegű elhelyezkedés, mivel a globális gazdasági növekedés keletrôl délre történő elmozdulása régiónk számára akár újabb kiugrási lehetőséget is biztosíthat a jövőben.

$\mathrm{Az}$ országcsoporttal összefüggésben jelen kutatásban az ún. függő piacgazdaságok elmélete, koncepciója merül fel. E megközelítés egyik legismertebb definiálása a Kapitalizmus változatai (Varieties of Capitalism) című, Hall-Soskice által publikált mű kapcsán jelent meg Nölke és Vliegenhart továbbfejlesztése révén az átmeneti gazdaságok feltárása végett. Különösen jelentős, hogy utóbbi értekezés a Visegrádi Négyek fejlődési modelljére vetíti ki a függő piacgazdaságok sajátosságait, valamint legfőbb tényezőként a külföldi tőke meghatározó szerepét jelölik meg.

Vajon milyen tényezők járulhattak hozzá legnagyobb mértékben a világgazdaságba, illetve szűkebb perspektívában az Európai Unióba történő integráció fokozódásához? Vajon számíthatunk-e a következő évtizedek folyamán további szignifikáns konvergenciára, felzárkózási előrelépésre, vagy pedig hosszú távon a vizsgált országcsoport, illetve régió kapcsán utóbbi feltételezések csak parciálisan teljesíthetőek? E tanulmányban feltételezzük, hogy az integrált periféria gazdaságok (például a KKE-i országok, ezen belül a kutatás magját képező V4 térség) a napjainkra már történelmi teherré avanzsált aszimmetrikus interdependenciájuk (ide értve a külső finanszírozástól való óriási függést, a kisebb felvevőpiacot, alacsony nyersanyag-ellátottságot, az 1989 utáni megelőző jelentős gazdasági elmaradottság kumulálódását) következtében képtelenek a hosszú távú, centrumhoz való teljes felzárkózáshoz a globális kapitalizmus jelen viszonyai közepette. A kutatás legfőbb hipotézise szerint tehát feltételezzük, hogy a régió fogyasztás alapú növekedése tovább fokozta a külső sokkoknak való kitettséget és a tartósan elhúzódó stagnálás kialakulását. 
Növekedési lassulások és a függő piacgazdaságok elmélete Kelet-Közép-Európa esetében Magyarország gazdasági növekedése a Visegrádi Csoport fejlődési útja fényében
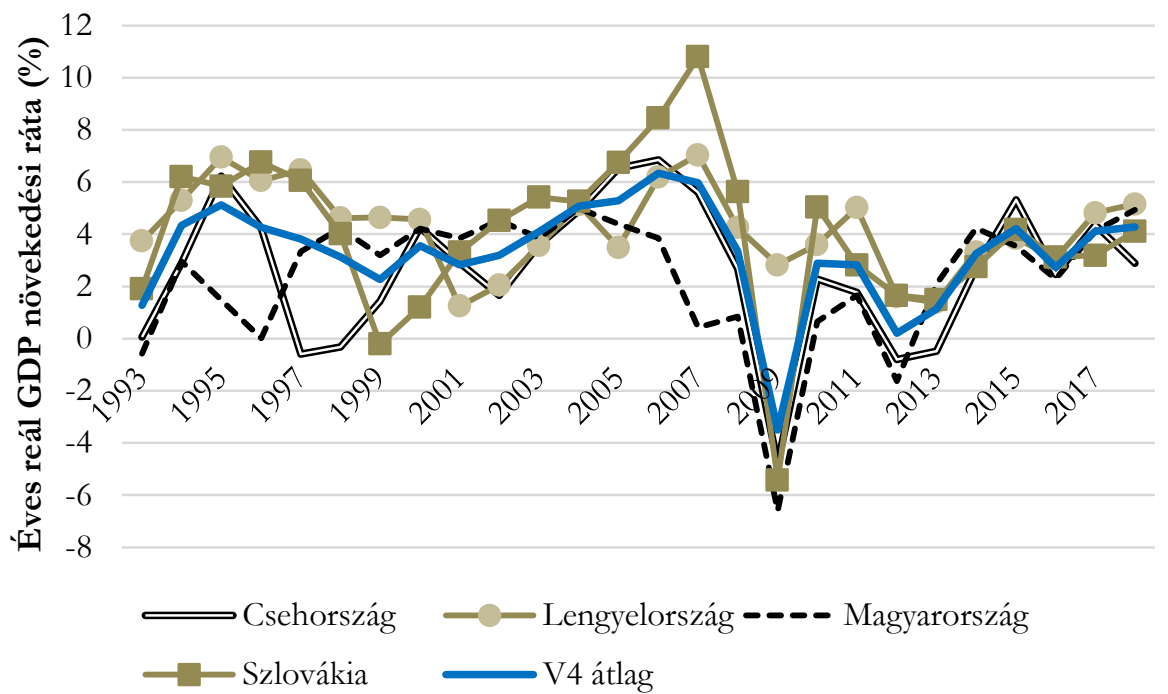

1. számú ábra: A V4-ek éves reál GDP növekedési rátája (1993-2018). ${ }^{2}$

Az 1. ábra a V4-es országcsoport éves reál Bruttó Hazai Termék növekedési rátáját illusztrálja. A Világbank World Development Indicators (a továbbiakban: WDI) rendelkezésre álló adatai a négy ország esetében 1993tól teszik lehetôvé a vizsgálódást egészen 2018-ig. ${ }^{3}$ Ahogy a vonaldiagram is szemlélteti, a rendszerváltás első néhány évében az 1994-95-ös transzformációs válság következtében jelentősebb gazdasági visszaesés tanúi lehettünk, azonban a térségbe egyre nagyobb volumenben beáramló FDI az 1990-es évtized második felében óriási löketet adott a GDP bővülésének. A következő mérföldkövet az Európai Unióhoz való csatlakozás jelentette, amely tovább fokozta a növekedés sebességét a térségben. A V4-ek közül az elemzett időszak során Szlovákia érte el 2007-ben, közvetlenül a krízis beáramlása előtt a legmagasabb értéket, 10,8\%-ot. A gazdasági és pénzügyi válság első nagyobb hatása 2009-ben állt elő, s ugyanebben az esztendőben a négy gazdaság közül hazánk produkálta a legalacsonyabb értéket $(-6,6 \%)$, amely egyben a teljes periódus minimumát is képezte. Meg kell jegyeznünk, hogy Magyarország számos évben, összesen 12 alkalommal rendelkezett a V4 csoport legalacsonyabb reál GDP növekedési rátájával: egyrészt a transzformációs válság, másrészt pedig a 2007-08-as krízis és recesszió

${ }^{2}$ Forrás: WDI, 2019 adatai alapján saját szerkesztés.

3 THE WORLD BANK, 2019. 
idején, melynek számos gazdaság- és monetáris politikai kiváltó oka is volt. Ugyanezen tényezőkből eredően a 2012-es, ún. W-alakú válság második ágában is hazánk volt a sereghajtó, de 2017-től már a V4-es átlag fölötti értéket sikerült elérni.

A régióban 2013-at követően már egyértelműen megindult a kilábalási tendencia: 2013 és 2016 között Csehország esetében figyelhettük meg a maximális értéket (5,31\%), miközben 2013-ban ugyanitt -0,48\%-os reál GDP növekedési ráta következett be. Elemzésünk során mindenképp ki kell emelni Lengyelország teljesítményét, amely kiválónak mutatkozott mind a V4, mind pedig a kelet-közép-európai térség országai közül. 1993-tól napjainkig gyakorlatilag nem is beszélhetünk negatív értékekről, s ez igen komoly eredménynek számít a legutóbbi válság övezte időszakra vetítve. A legkisebb érték (1,25\%) 2001-ben, míg a legmagasabb 2007-ben (7,03\%) következett be. 2010-ben és 2011-ben is az előző évhez képest emelkedést láthattunk, azonban 2012-re 3,41 százalékpontos csökkenés került terítékre, habár így is pozitív értéket őrizhetett meg a gazdaság.

A McKinsey Global Institute 2013-as elemzésében azt a javaslatot fogalmazta meg a kelet-közép-európai térség további felzárkózását illetően, hogy a fogyasztás helyett beruházás alapú növekedést kell megvalósítani, valamint bővíteni a régió növekedést finanszírozó lehetőségeit többek között az exporttevékenység további fokozása és a hazai elmaradottabb szektorok termelékenységének gyarapítása révén. Utóbbi növekedési terv legfőbb alkotóelemei az infrastrukturális, oktatási és innovációba fektetett beruházások, illetve az intézményi reformok ${ }^{4}$.

\section{AZ FDI GAZDASÁGI NÖVEKEDÉSRE GYAKOROLT HATÁSA}

Egy felzárkózási pályán lévő ország további növekedésében igen komoly szerepet játszanak az olyan tényezők, mint az aktuális gazdasági, politikai környezet, a kereskedelmi kapcsolatok intenzitása, valamint ebből fakadóan a külföldi tôke jelenléte és dinamikája. A V4-ek tekintetében hangsúlyozni szükséges, hogy a rendszerváltást követő turbulens időszak többek között azzal is fémjelezhető, hogy az Európai Unióhoz való, későbbiekben előkészitésre kerülő időszak a külföldi mûködőtôkebefektetések intenzitását idézte elő. Azonban felmerül a kérdés, hogy érdemes-e egyáltalán a külföldi tőke jelenlétének tulajdonítani hosszabb

\footnotetext{
${ }^{4}$ LABAYE et al., 2013.
} 
távon egy-egy gazdaság, régió felzárkózását, valamint megállapítható-e egyértelműen, hogy az FDI áramlások okozzák a gazdasági növekedést vagy pedig utóbbi idézi elő előbbi folyamatokat nagyobb mértékben. A kétirányú kapcsolat vizsgálatára számos kutatás született, azonban egyik megállapítás sem vált kvázi mainstream elméletté az elmúlt évtizedek során. Ami bizonyosan kimutatható, az nem más, mint az a tény, hogy a külföldi múködőtőke-beáramlás pozitív hatásai a fejlett országokban a legszignifikánsabbak, mivel utóbbiak rendelkeznek azzal a kapacitással, amellyel jóval hatékonyabban és nagyobb mértékben tudják befogadni a kedvező folyományokat. ${ }^{5}$ Így tehát a centrum gazdaságok kezdeti előnyeiknek köszönhetően az FDI beáramlások sikeresnek mondható hasznosítása révén kumulatív előnyökre tesznek szert, s így közvetve hozzájárulnak az országok közötti egyenlőtlenségek további növekedéséhez. ${ }^{6}$ További fontos kitétel, hogy a kelet-közép-európai országok gyakorlatilag sokkterápia jelleggel igyekeztek átállni az új gazdasági-politikai berendezkedésre az 1990-es évtized első felében a privatizáció igen gyors kivitelezése formájában, amely a későbbiekben számos problémát idézett elő, mint például a fejletlen intézmények, bankrendszer és egyéb tényezők okozta, külföldi tőkén való egyre nagyobb mértékű dependencia kialakulása. ${ }^{7}$

Amennyiben globálisan kívánjuk áttekinteni a működőtőke-áramlás tendenciát, meg kell jegyezni, hogy az ezredfordulót követően a világgazdaságban kisebb visszaesés volt tapasztalható a centrum országokban kialakuló csökkenés miatt, azonban 2004-től kedvezőbb időszak állt elő. Ebben a periódusban a kevésbé fejlett országokban a visszaesés kisebb mértékben volt jelen, sőt, némi emelkedés is létrejöhetett a működőtőkét illetően. 2004 után a külföldi tőkeállomány bruttó hazai termékhez viszonyított aránya a fejlett gazdaságok javára billent. Számos folyamat tükrözte, hogy a tőke fokozott áramlása az olyan területekre is kezdett átterjedni, mint például Afrika, ahol nem csak az Egyesült Államok, hanem Kína is egyre nagyobb mértékü beruházásokat generált. ${ }^{8}$

Amennyiben nemzetállami szinten elemezzük a külföldi múködőtőke hatásait, bizonyos externáliákat is szükséges kiemelni, mint például az országon belüli regionális egyenlőtlenségek fokozódása, amely hazánkban is tetten érhető. A telephelyként funkcionáló régiók egyértelműen fokozták a

${ }^{5}$ CARBOnELl - WERnER, 2018.

${ }^{6}$ ARTNER, 2014.

${ }^{7}$ Curwin - Mahutga, 2014.

8 ARTNER, 2014. 
fejlődést a nagyobb tôkeinjekció révén, a munkahelyteremtés által pedig többletjövedelmet teremtettek az aktív munkavállalók számára. A kevésbé sikeres régiók pedig a perifériára sodródva számos kezdeti előnytől estek el, amely a későbbiekben tovább nehezítette a centrumhoz való konvergencia megvalósulását. Utóbbiak kapcsán az Európai Unió regionális támogatásai sem tudtak minden esetben jelentős előrelépést elérni. ${ }^{9}$

Tanulmányunk keretében feltételezzük, hogy egy adott gazdaság vagy országcsoport hosszú távú konvergenciájához abban az esetben lehet közelebb kerülni, amennyiben egy nagyobb növekedési időszak után nem alakul ki olyan periódus, melynek sajátossága a relatíve magas folyó fizetési mérleg hiány fennállása. Utóbbi feltételezés azért is indokolt, mert a tartósabb folyó fizetési mérleg deficit eredményeként jelentős külső adósságtömeg gyülemlik fel. Ugyanekkor a befolyó külföldi múködőtőkebefektetések egyre kevesebb eszközt hagynak a hazai vállalkozások, valamint háztartások esetében. A külföldi tulajdoni ráta bővülése bizonyos idő eltelte után egyre inkább szúkíti a bruttó hazai termék, valamint a bruttó nemzeti jövedelem közötti rést. A jelentősebb FDI inflow (ezen kívül pedig alacsonyabb hányadban portfólió beruházás és adósságfinanszírozás) révén múködő szignifikáns növekedési periódusok kapcsán gyakran halhattunk a valutaválságok kialakulásának párhuzamáról. Ehhez kötődően három epizód is felmerül: az 1994 és 1995 közötti mexikói peso válság, az 1997-ben bekövetkező kelet-ázsiai krízis, illetve az 1998-2002-es argentin válság. Az említett jelenségekkel kapcsolatban megfigyelhető, hogy az érintett országok az adott idôszakban közepes jövedelmú gazdaságok voltak, illetve a krízisek egy gyorsuló növekedési szakaszt követően bontakoztak ki.

${ }^{9}$ ANTALÓCZY - SASS, 2005. 
Növekedési lassulások és a függő piacgazdaságok elmélete Kelet-Közép-Európa esetében Magyarország gazdasági növekedése a Visegrádi Csoport fejlődési útja fényében
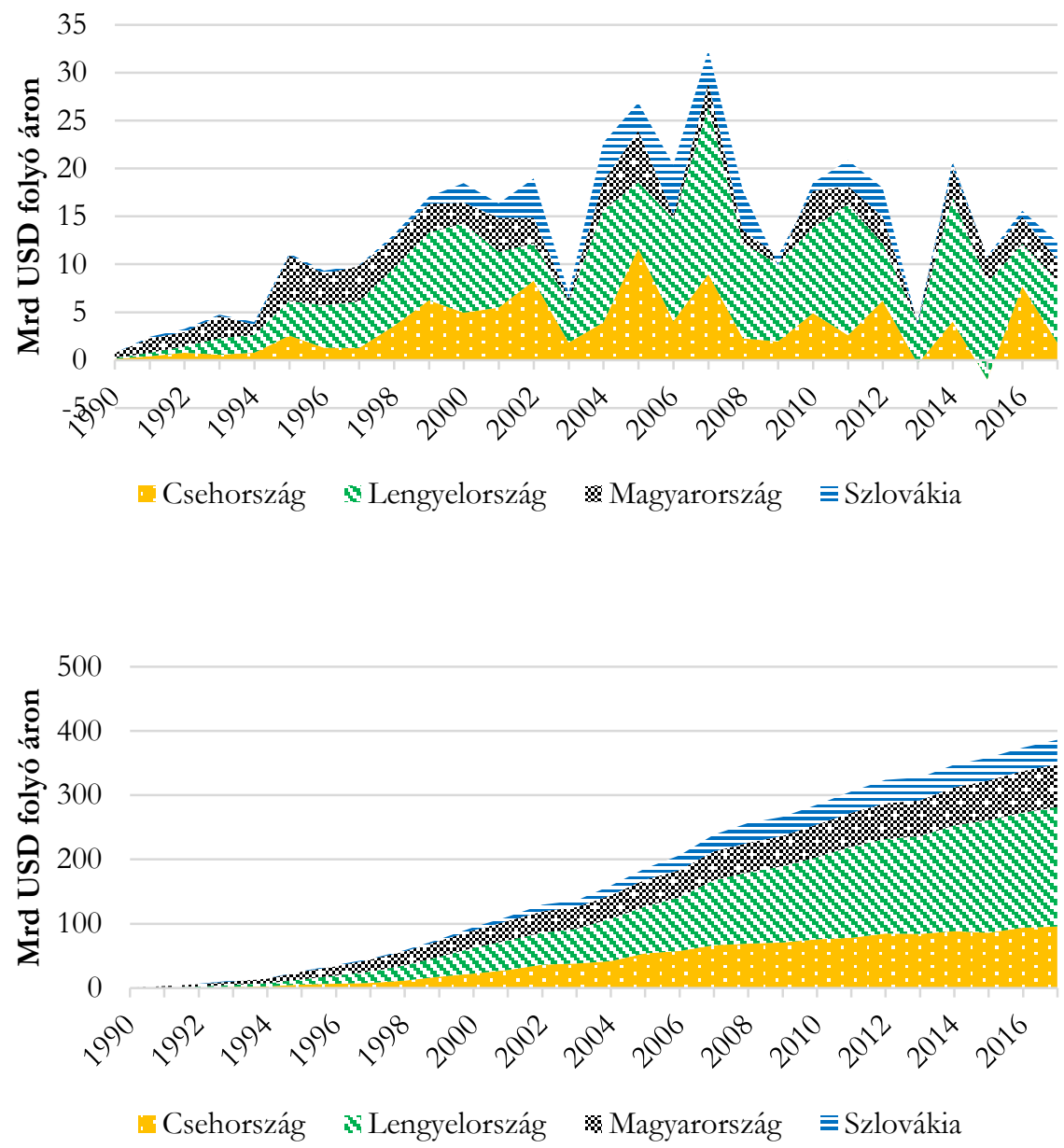

2. számú ábra-együttes: Éves és kumulatív nettó FDI milliárd dollárban folyó áron 1990-től 2017-ig ${ }^{10}$.

A 2. ábra-együttes első diagramja az éves FDI beáramlás és kiáramlás különbözetét jeleníti meg folyó áron kalkulált milliárd dollárban a WDI (Szlovákia esetében a tanulmány megírásakor még nem állt rendelkezésre a 2018-as adat, így csak 2017-ig került vizsgálatra az adatsor) és az

${ }^{10}$ WDI, 2019. és UNCTADSTAT, 2019. adatai alapján saját szerkesztés. 
UNCTADstat adataira támaszkodva. ${ }^{11}$ A kapott alakzatok területe elsôsorban az adott nemzetállamok népességétől függ. A legmagasabb FDI állomány Lengyelországban figyelhető meg, hiszen ez a tagállam adja a teljes V4 csoport súlyának több mint 60\%-át 38 millió fős népességével. A lengyeleket a csehek követik a német piaccal való szoros összefonódásnak köszönhetően. A harmadik helyen hazánk szerepel, majd pedig Szlovákia, a Visegrádi Négyek legkisebb gazdasága volumen tekintetében. Az is egyértelmúen megállapítható, hogy az 1990 és 2016 közötti időszakban összesen három szakasz különböztethető meg: az első fázis a rendszerváltás óta 2003-ig tartott, amely az EU-s csatlakozást megelőző év átmeneti állapotát jeleníti meg, hiszen ekkor számos befektető előretekintő jelleggel a 2004-es csatlakozási időpontot várta meg. A második diagram már kumulatívan illusztrálja az évről évre felhalmozódó FDI-t a régión belül. A rendszerváltás után egyre nagyobb mértékben befolyó külföldi közvetlen tőke nagyjából 10-15 éven keresztül maradt relatíve igen magas intenzitáson, azonban a folyamat - habár jóval kisebb meredekség fenntartása mellett napjainkban is erőteljesen érvényesül. A következő jelentős periódus a 2004es csatlakozástól egészen a 2008-as gazdasági és pénzügyi válság térségünkbe való beszivárgásáig tartott, amely igen magas FDI állomány megvalósítását tette lehetôvé.

Harmadik szakaszként pedig a W-alakú válság 2012-es második fázisa után állt elő, amikor ugyanis már kisebb volumenű FDI áramlások szemtanúi lehettünk a V4 tagállamaiban. Utóbbi folyamat napjainkban is tart. Ezt követően érdemes megvizsgálni a V4 tagországok egy főre eső kumulatív nettó FDI állományának alakulását. A fenti két ábrával ellentétben, ahol a magas népességnek köszönhetően Lengyelország került az első helyre, utóbbi gazdaság a 3. számú ábrán egy főre jutóan a legalacsonyabb FDI értékkel bír, mivel nagyobb belső piaccal és relatíve kisebb nyitottsággal rendelkezik a V4 többi országaihoz képest. Ezen felül pedig jóval nagyobb a nemzeti tulajdon aránya is utóbbi nemzetállamban. 2016-ban 4751 dollár volt a fejenkénti nettó FDI állomány. A magyar és a szlovák érték az elmúlt esztendőben nagyjából azonos szintű volt (6551 és 6404 USD/per fö), míg a legnagyobb állomány a cseheknél állt elő (8703 USD/fö) 2016-ban. Csehország egyébként 2002 óta tartja az első helyezést a vizsgált paramétert illetően, amikor hazánk elé sikerült jutnia 3726 dolláros

${ }^{11}$ UNCTAD, 2019. 
Növekedési lassulások és a függő piacgazdaságok elmélete Kelet-Közép-Európa esetében Magyarország gazdasági növekedése a Visegrádi Csoport fejlődési útja fényében

egy főre eső nettó FDI állományával, ráadásul itt az egy főre jutó GDP is jóval nagyobb, mint a többi országban.

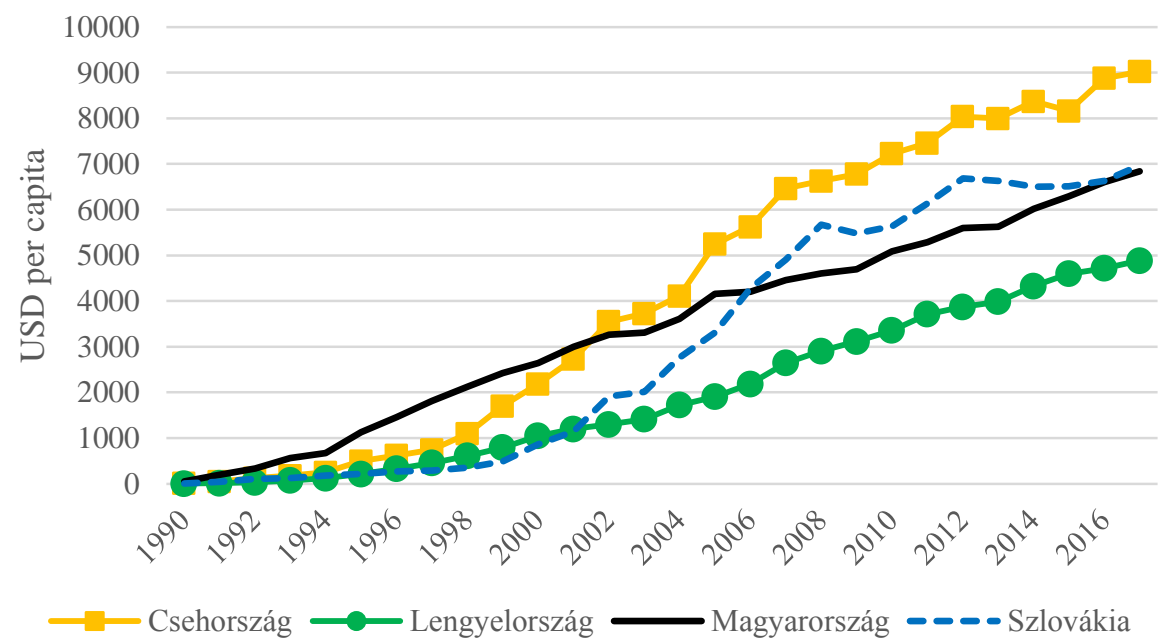

3. számú ábra: Egy főre eső kumulatív nettó FDI állomány dollárban folyóáron (1990-2017). ${ }^{12}$

\section{A BRUTTÓ HAZAI TERMÉK NÖVEKEDÉSE ÉS A FOLYÓ FIZETÉSI MÉRLEG KÖZÖTTI KAPCSOLAT VIZSGÁLATA}

Ahhoz, hogy a korábban már megfogalmazott feltételezésünk alaposabb vizsgálat tárgyát képezhesse, a 4. számú ábrát vezetjük be elemzésünk eredményeként, amely az éves reál GDP növekedési ráták és folyó fizetési mérleg közötti összefüggést mutatja be. Ahhoz, hogy viszonylag pontos eredményekre jussunk, a V4-es tagállamok körét kibővítjük néhány további kelet-közép-európai országgal: Bulgária, Horvátország, Románia és Szlovénia. A pontdiagram elkészítése során adatpáronként ábrázoltuk a vizsgált gazdaságokat, illetve éveket az 1996 és 2016 közötti periódusra. A kék szín a válság előtti, a piros pedig a krízist követő adatokat jeleníti meg. Megállapítható, hogy az éves GDP növekedés, illetve a folyó fizetési mérleg GDP-hez viszonyított aránya között szignifikáns összefüggés áll fenn, ezen kívül pedig strukturális töréspontok nem alakultak ki.

12 WDI, 2019. és UNCTADsTAT, 2019. adatai alapján saját szerkesztés. 
Ami a konkrét számokat illeti, a WDI és az Eurostat ${ }^{13}$ adatait felhasználva kiszámítható, hogy a folyó fizetési mérleg egyenlegének koefficiense -0,319-es értéket vesz fel, amely tehát azt jelenti, hogy amennyiben a folyó fizetési mérleg egyenlege 1 százalékpontot esik, a GDP ráta 0,319 százalékpontot nő. Ezen felül a kereskedelmi nyitottság, illetve a Fraser Institute által publikált Economic Freedom Index ${ }^{14}$ is felmerült, mint potenciális tényező, azonban a számítások alapján egyértelművé vált, hogy e két esetben a kapcsolat szorossága már nem mondható szignifikánsnak. A folyó fizetési mérleg egyenleg, valamint az FDI inflow tekintetében Rapacki és Próchniak is hasonló párhuzamot állapítottak meg, valamint a strukturális reformok fejlődésére irányították kutatásukat a kelet-közép-európai régióban a reál konvergenciával összefüggésben. ${ }^{15}$

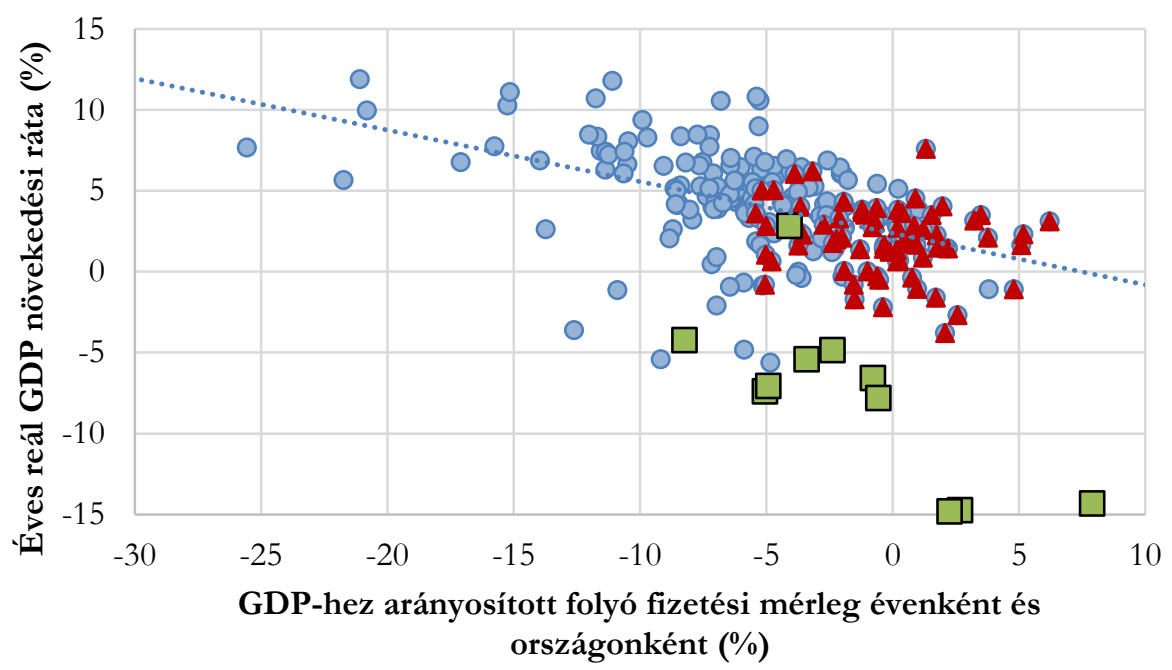

0 1996-2008 \ 2010-2015 $\square 2009$

4. számú ábra: Az éves reál GDP növekedési ráták és folyó fizetési mérleg közötti összefüggés 8 választott kelet-közép-európai országban (19962015). ${ }^{16}$

\footnotetext{
13 EUROPEAN COMMISSION, 2019.

14 THE Fraser INSTITUTE, 2018.

15 RAPACKI - PRÓCHNIAK, 2009.

16 WDI, 2019. és EUROSTAT, 2019. adatai alapján saját szerkesztés.
} 
Amennyiben a V4 országokat gazdasági teljesítményük alapján rangsorolni kívánjuk, a 2015-ös adatok alapján a vásárlóerő-paritáson vett egy főre eső Bruttó Hazai Termék szerint Csehország képezte a csoport legfejlettebb gazdaságát, melyet Szlovákia, Lengyelország és végül Magyarország követte. A fentebb már felsorolt és egyéb paraméterek GDP növekedésre gyakorolt hatásáról Simionescu Mihaela és szerzőtársai 2017-es tanulmányában az alábbi összefüggések kerültek megállapításra. Egyrészt a $\mathrm{K}+\mathrm{F}$-re fordított kiadások pozitívan korreláltak a növekedéssel Csehország és Magyarország esetében, azonban Lengyelországban és Szlovákiában éppen ellentétes irányú hatásokat generált. Másrészt, az FDI összességében pozitív hatást gyakorolt Szlovákia kivételével mindhárom gazdaságban a növekedésre. Harmadrészt pedig az oktatásba fektetett állami kiadások csupán Csehországban mutattak pozitív összefüggést a növekedéssel, a többi három országban viszont negatív korreláció állt elő az elemzések során. ${ }^{17}$

Egyet kell érteni azzal a kijelentéssel, hogy közép-, illetve hosszú távon a humántőkére irányuló beruházások a növekedés, felzárkózás motorjaként szolgálnak különösképpen az olyan tranzit gazdaságoknál, mint a Visegrádi Csoport. A magasan képzett humántőke-bázis lehetővé teszi a megfelelő kutatás-fejlesztési tevékenység megalapozását, amely a versenyképesség fenntartásának záloga. Ami pedig kifejezetten hosszú távon szolgálja a stabil gazdasági növekedést, az kétségtelenül az oktatásra fordított kiadások, beruházások fokozatos bővítése. ${ }^{18}$ Habár másfelől, a fejlett centrum országoknak gazdasági szempontból nem feltétlenül kedvezne a régió, jelenleg olcsó és könnyen elérhető munkaerejének nagyobb mértékű felzárkóztatása és ezáltal magasabb béreken történő bekapcsolása a globális munkamegosztási folyamatokba.

\footnotetext{
17 SimiOneSCU et al., 2017.

18 SIMIONESCU et al., 2017.
} 


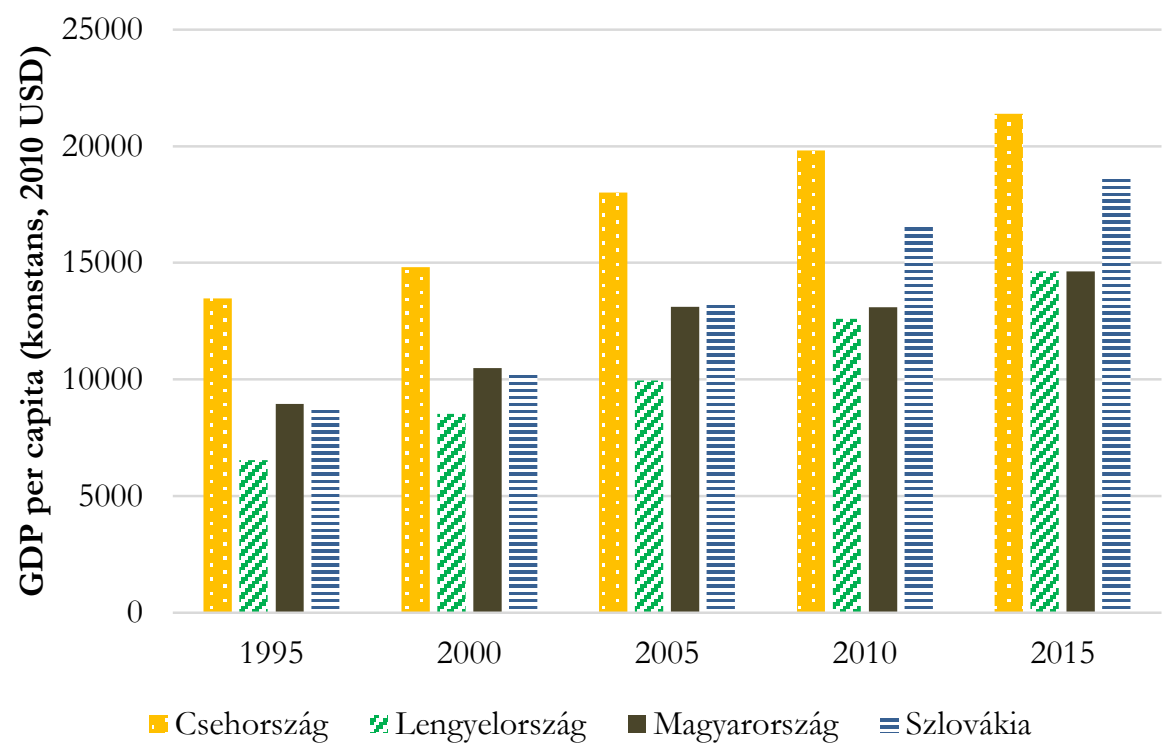

5. számú ábra: Öt éves intervallumonként ábrázolt egy főre eső GDP (19952015). ${ }^{19}$

A gazdasági növekedés, felzárkózás egy további fokmérőjeként érdemes megvizsgálni a négy ország egy főre eső GDP-jének alakulását. Az 5. ábra öt éves szakaszonként jeleníti meg a transzformációs válságot követő időszaktól 2015-ig tartó fejlődési utat. Az egy főre jutó GDP tekintetében a teljes periódus alatt Csehország teljesített a legjobban. Magyarország és Szlovákia 2005-ig közel azonos szintet hoztak, majd pedig 2010-től váltak el élesebben egymástól a szlovák gazdaság felívelésével, ahol 2009-ben került bevezetésre az euró. Lengyelország pedig igen stabil és fokozatos növekedést valósított meg annak ellenére, hogy a négy tagállam közül 1995-ben itt tapasztalhattuk a legalacsonyabb egy före jutó GDP értéket. Az arányokat elemezve kiderül, hogy a cseheknél az első vizsgált évhez képest 2015-re több mint másfélszeres növekedés állt be, a lengyeleknél ez a ráta 2,24szeres, s így a csoport legnagyobb mértékű bővülését könyvelhették el, hazánkban 1,63-szoros emelkedés volt tetten érhető, a szlovákoknál pedig 2,15-szörös volt az 1995-ről 2015-re bekövetkező egy főre jutó GDP növekedést.

${ }^{19}$ WDI, 2019. adatai alapján saját szerkesztés. 


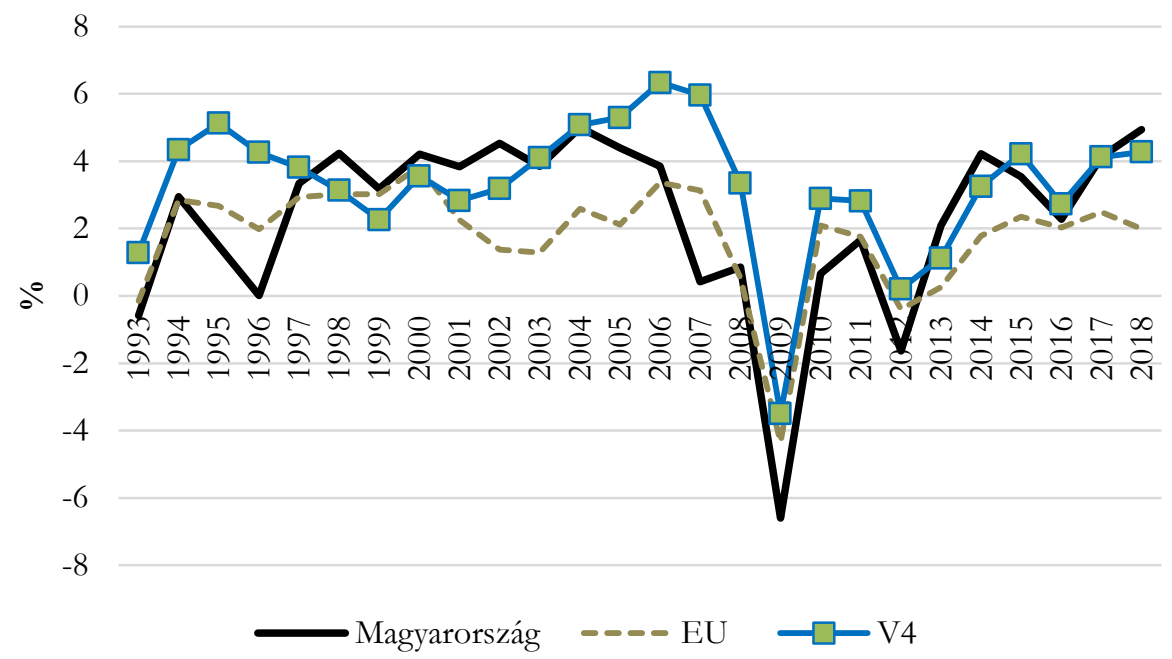

6. számú ábra: Magyarország, a V4 és az Európai Unió éves reál GDP növekedési rátája (1993-2018). ${ }^{20}$

A V4-ek közül következő lépésként hazánk, a Visegrádi Négyek és az EU reál GDP növekedési rátája kerül vizsgálatra az 1992-tôl 2018-ig tartó periódusban (6. ábra). Az említett időszakban gyakorlatilag három szignifikáns növekedésbeli visszaesés állt elő: első körben a transzformációs krízis okozott jelentős GDP csökkenést a magyar gazdaságban. Ezt követően a 2007-08-as válság 2009-es mélypontja - mint ahogy már említettük is, a V4 csoportban elért legalacsonyabb ráta - a 2012-ben megfigyelhető második leszálló szakasszal folytatódott, amely a W-alakú recesszió eredményeként lépett fel Magyarországon. E jelenség a többi kelet-közép-európai gazdaságban is tetten érhetô volt: a válságot követő átmeneti GDP bővülés után lassulási tendencia indult meg, viszont ezúttal már kisebb mértékű csökkenést vont maga után. Hogy néhány konkrét rátát is felsorakoztassunk, 2009-ben hazánkban $-6,6 \%$ volt a Bruttó Hazai Termék, miközben az európai uniós átlag -4,36\%-ot tett ki. A következő visszaesési fázisban, 2012-ben pedig a két érték -1,64\% és 0,43\% volt. ${ }^{21}$

${ }^{20}$ WDI, 2019. adatai alapján saját szerkesztés.

21 THE WORLD BANK, 2019. 


\section{A V4 GAZDASÁGOK KÖZEPES JÖVEDELMI CSAPDA EPIZÓDJAI}

A fejezet keretében egy rövid elemzés formájában megvizsgáljuk a régió gazdasági növekedésében bekövetkező jelentősebb lassulási szakaszokat. A felzárkózási út elmúlt néhány évtizedben tapasztalt alakulásában néhány ország esetében - érdekes tendenciákat tárhatunk fel. Vajon milyen okból jönnek létre a jelentősebb, tartósabb lassulási fázisok, illetve mindez hogyan tükröződik a felzárkózás folyamatán? A növekedéselmélet és fejlődés-gazdaságtan diszciplínái lehetőséget nyújtanak arra, hogy közelebbről is megvizsgálhassuk az egyes országok, országcsoportok növekedési lassulásait, amelyek a legutóbbi gazdasági válság óta ismét egyre nagyobb jelentőséggel bírnak. Geoffrey Garrett 2004-es kutatásában a közepes jövedelmű országok növekedési problémáit elemezte és azt hangsúlyozta, hogy a globalizáció támogatói nem tudnak logikus magyarázattal szolgálni azon lassulási periódusokra, amelyek jelenleg számos közepes jövedelmú gazdaságban zajlanak. ${ }^{22}$ A napjainkban egyre gyakrabban gazdasági, illetve gazdaságpolitikai elemzések tárgyát képező, ún. közepes jövedelmi csapda jelensége egyrészt módszertanként szolgál a jelentős lassulási epizódok felderítésére az egyes országok növekedési útjában, másrészt pedig állandó vitafelületet is nyújt a megoldási javaslatok kidolgozása végett a további lehetséges felzárkózási szcenáriókat illetően.

Mint ismert, a Világbank évente nyilvánosságra hozza világgazdaságunk országait csoportosító jövedelmi kategóriákat. A jelenlegi klasszifikáció szerint a 28 uniós tagországból mindössze Bulgária és Románia tartoznak a felső-közép jövedelmi csoportba, a többi tagország pedig már a felső kategóriába sorolható a rendszer indikátorai szerint. Azonban kutatásunkban egy saját klasszifikációs módszert vezetünk be az alábbiak szerint. Ahhoz, hogy a négy jövedelmi csoport intervallumait pontosan definiáljuk, az adott ország egy főre esô GDP-jét el kell elosztanunk a világ egy főre eső GDP-jével. Amennyiben ez a ráta 50 százalék alatti értéket ad, úgy alacsony jövedelmű gazdaságként tartjuk számon a vizsgált országot. 50\% és 100\% között alsó-közép, 100\% és 200\% között felső-közép, 200\% fölött pedig magas jövedelmű gazdaságokról beszélünk. A már említett közepes jövedelmi csapda jelensége jellemzően tehát egy magasabb növekedési szakasz következtében áll elő tartós lassulást eredményezve. Ahhoz, hogy egy-egy ilyen epizódot azonosítani tudjunk,

\footnotetext{
22 GARRETT, 2004.
} 
Növekedési lassulások és a függő piacgazdaságok elmélete Kelet-Közép-Európa esetében Magyarország gazdasági növekedése a Visegrádi Csoport fejlődési útja fényében

meg kell vizsgálni, hogy a lassulást megelőző 10 évben fennállt-e a már említett gyors gazdasági növekedés. Ezen felül a jövedelmi csapdában lévő ország felzárkózási pályát jár be 10 éves átlagban 3\%-os egy főre eső GDP mellett. Továbbá fontos hangsúlyozni, hogy növekedési lassulás alatt stagnálást, nem pedig hirtelen recessziót kell érteni. A legalább 10 éven át tartó lassulási fázis során az egy före jutó GDP növekedés nullához közeli vagy legfeljebb $1 \%$ évente.

\begin{tabular}{|c|c|c|c|c|c|c|c|c|c|c|c|c|}
\hline \multirow[b]{2}{*}{ Országok } & \multicolumn{3}{|c|}{ Növekedési időszak } & \multicolumn{6}{|c|}{ Lassulási időszak } & \multicolumn{3}{|c|}{ Utólagos növekedési ráta } \\
\hline & 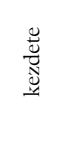 & $\stackrel{8}{\circ}$ & $\frac{d}{\frac{b}{\circ}}$ & 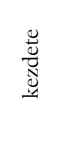 & 范 & 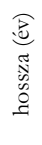 & $\frac{d}{20}$ & 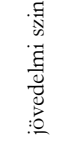 & $\begin{array}{l}\text { t. } \\
0 \\
0 \\
0 \\
0 \\
0\end{array}$ & $\stackrel{d}{-}$ & 范 & $\frac{\frac{b}{d}}{0^{\circ}}$ \\
\hline Lengyelország & 1953 & 1975 & 3,72 & 1976 & 1989 & $\begin{array}{l}1 \\
4\end{array}$ & $-0,11$ & $141 \%$ & $\begin{array}{l}\text { felső- } \\
\text { közép }\end{array}$ & 1992 & $\begin{array}{l}\text { napja- } \\
\text { inkig }\end{array}$ & 4,19 \\
\hline Magyarország & 1957 & 1978 & 3,57 & 1979 & 1989 & $\begin{array}{l}1 \\
1 \\
\end{array}$ & 0,92 & $185 \%$ & $\begin{array}{l}\text { felsô- } \\
\text { közép } \\
\end{array}$ & 1994 & 2005 & 3,61 \\
\hline Magyarország & 1994 & 2005 & 3,61 & 2006 & 2015 & $\begin{array}{l}1 \\
0\end{array}$ & 0,82 & $177 \%$ & $\begin{array}{l}\text { felső- } \\
\text { közép }\end{array}$ & \multicolumn{3}{|c|}{ lassulás vége 2014-2015-ben } \\
\hline
\end{tabular}

1. számú táblázat: Növekedési és lassulási periódusok a visegrádi országokban. ${ }^{23}$

$A z$ 1. táblázatban ${ }^{24}$ az általunk, előzőekben már felsorolt $8 \mathrm{KKE}-\mathrm{i}$ ország kapcsán összesen három jövedelmi csapda epizód alakult ki az elmúlt évtizedek során. Ami a legérdekesebb, hogy a kettő érintett ország V4-es gazdaság is egyben, ahol tehát három csapdahelyzet állt elő. Lengyelországban 1953-tól 1975-ig egy szignifikáns növekedési időszak állt fenn átlagosan 3,72\%-os éves növekedési rátával, majd pedig 1976-tól egy 14 éven át tartó stagnálás következett (0,11\%/év). 1992-től ismételten megindult a növekedés, amely napjainkban is tart. Magyarországon azonban kettő közepes jövedelmi csapda szituáció is létrejött. Az első esetet egy 1957-tôl 1978-ig tartó növekedési fázis előzte meg (3,57\%-os átlagnövekedéssel), majd pedig 1979-től 1989-ig szignifikáns lassulási tendencia bontakozott ki átlagosan 0,92\%-os növekedési rátával. 1994-től 2005-ig pedig a soron következő növekedési szakaszba léphetett hazánk. A második jövedelmi csapda előtt 1994-től egészen 2005-ig az előzőekhez hasonlóan

${ }^{23}$ WDI, 2019. és GGDC, 2013. adatai alapján saját szerkesztés.

24 The Maddison-Project (GGDC), 2013; The World Bank, 2019. 
jelentős növekedés volt folyamatban, amelyet a transzformációs válságból való kilábalás, illetve a régióba beáramló FDI indukálta. Azonban 2006-tól részben endogén hatásokra (folyó fizetési mérleg deficit csökkentésére irányuló intézkedések), illetve néhány évvel később a gazdasági válság miatt komoly visszaesés indult meg, amely nagyjából 2014-2015-ig tartott.

A tartós növekedési lassulásokkal kapcsolatos gondolatmenetet folytatva további elemzésünket a 2007-08-as válság, illetve recesszió Visegrádi Csoport kettő, fentebb bemutatott csapdával érintett tagjára gyakorolt hatásaira irányítjuk, hiszen igen egyértelmú, hogy a krízis nagyon különböző módon érintette a lengyel és magyar gazdaságot. Az egyik első megállapítunk az, hogy ugyan 2008 előtt a régióban a külső finanszírozás vitális szerepet játszott a bruttó hazai termék bővülésében, a hazai fogyasztás rendszeresen meghaladta a GNI-t mindkét ország esetében. Ennek folyományaként a fizetési mérleg hosszú távon jelentős hiányt mutatott, s utóbbit a szufficites tôkemérleggel kísérelték meg ellensúlyozni. Azonban 2008-at követően a pénzügyi válság nagymértékben beszűkítette a térségünk által nyújtott finanszírozási lehetőségeket, különösképpen hazánkban, ahol a külföldi befektetők túlzottan kockázatosnak ítélték meg jövőbeli beruházásaikat a jellemzően devizában történt magas állami és magánszektorbeli eladósodás, illetve a kedvezőtlen makrogazdasági teljesítmény miatt is. Magyarországon 2008 októberében a központi bank 3 százalékponttal emelte a jegybanki alapkamatot egyetlen nap leforgása alatt. Ezen felül pedig a kormány tárgyalásokat indított a Nemzetközi Valutaalappal hitelfelvétel ügyében, mivel a piaci alapú finanszírozás már tarthatatlanná vált a gazdaság számára. 2008 és 2009 között hazánkban a folyó fizetési mérleg egyenlege 7 százalékponttal emelkedett, melynek hatására a külső finanszírozás gyakorlatilag megszűnt, a háztartások fogyasztása és a beruházások jelentősen csökkentek, a GDP 7 százalékponttal esett egy év alatt, s ezáltal igen komoly recesszió lépett fel a következő időszak folyamán.

Ami Lengyelországot illeti, utóbbi gazdaságban szintén deficit állt fenn 2008-at megelőzően, azonban jóval alacsonyabb mértékben, mint hazánkban (nagyjából 2-5\% között). A válság első szakaszában az állami és magánszektorban fennálló eladósodás szintén kisebb volumenú volt, s így a külső finanszírozás fenntarthatónak bizonyult 2008-09-ben, illetve a válság beáramlását követő további néhány évben. Viszont a leglényegesebb eleme a lengyel válságkezelésnek nem más, mint a radikális korrekciók hiánya. Az Unióban fennálló recessziós időszak során a lengyel gazdaságpolitikai intézkedéseket nyolc év folyamán hajtották végre. E fokozatosságnak hála a 
Növekedési lassulások és a függő piacgazdaságok elmélete Kelet-Közép-Európa esetében Magyarország gazdasági növekedése a Visegrádi Csoport fejlődési útja fényében

gazdasági szereplők alkalmazkodni tudtak a kedvezőtlenebb körülményekhez, illetve a kiigazító intézkedésekhez is. Eredményképpen nem állt elő recesszió 2008-ban, 2010 után pedig viszonylag magas növekedés is megindult az országban.

\section{KONKLÚZIÓ}

Nem vitatható azon tény, hogy a kelet-közép-európai térség országai a piacgazdasági átmenetet követő, transzformációs válságtól és komoly társadalmi feszültségektôl terhes időszaka után képesek voltak egy viszonylag gyors gazdasági növekedési úton elindulni és ezáltal jelentős felzárkózást elérni. E sikeres növekedési epizód alapvetően a térségbe óriási volumenben beáramló FDI állomány segítségével valósulhatott meg, amely különösképpen az Európai Unióhoz való csatlakozást követően vált még inkább vonzó lehetôséggé a külföldi befektetôk számára. Azonban amint a legutóbbi gazdasági és pénzügyi válság is előtérbe helyezte, a legnagyobb mértékben FDI beáramlás által hajtott növekedés hosszú távon nem bizonyult fenntarthatónak. A krízis során tapasztalhattuk, hogy az Unió perifériáján lévő országok mennyire érzékenyen reagáltak a külső sokkokra, illetve hogy valójában milyen törékeny az elmúlt évtizedekben megvalósított fejlődésük. A KKE-i nemzetállamok fejlődésére jellemző még az ún. függő piacgazdaságok modellje, amely évtizedek alatt meglehetősen kedvezőtlen, kockázatos hátteret alakít ki a pénzügyi, humán és társadalmi tôke számára. A külső finanszírozástól való ilyen mértékű dependencia valójában tehát történelmi teherré avanzsált a tranzit országok hosszú távú felzárkózásában, amely napjainkban már nemcsak a fejlett, központi országoktól, hanem többek között a multi- és transznacionális vállalatoktól való óriási mértékú függés formájában tapasztalható. ${ }^{25} \mathrm{Az}$ olcsó munkaerő, összeszerelő tevékenység és a kiszervezett üzleti szolgáltatóközpontok (SSC-k) előtérbe juttatása még mélyebbre juttatja azt a képzeletbeli horgonyt, amely többek között hazánk gazdasági fejlődését is szignifikánsan visszavetette az elmúlt időszak folyamán.

E tanulmányban megállapításra került, hogy a Bruttó Hazai Termék növekedése igen szoros kapcsolatban áll egyrészt folyó fizetési mérleg egyensúlyának, másrészt pedig a beáramló külföldi közvetlen múködőtőkeberuházások alakulásával. Ezen felül kimutattuk azt is, hogy a nyolc -

25 GÁL - SCHMIDT, 2017. 
szélesebb perspektívából elemzett - kelet-közép-európai gazdaság közül egyedül Lengyelország és Magyarország tapasztalt közepes jövedelmi csapda epizódokat. Míg előbbi országban a növekedési fázis napjainkban is teljesül, illetve igen sikeres válságkezelési stratégiák kerültek megvalósításra az elmúlt néhány év folyamán, melyek lehetôséget adtak a külső finanszírozóknak, illetve egyéb piaci szereplőknek a fokozatos alkalmazkodásra, addig hazánkban a sokkterápiás jellegű gazdaságpolitikai intézkedések hatására 2008-ról 2009-re 7 százalékponttal emelkedett a folyó fizetési mérleg egyenlege, illetve egy elhúzódó recessziós periódus alakult ki. A válság során tehát további bizonyítást nyert, hogy a régió fogyasztás alapú növekedése tovább fokozta a külső sokkoknak való kitettséget és a tartósan elhúzódó stagnálás kialakulását. 2005 és 2008 között a klasszikus értelemben vett KKE-i régió GDP-jének 80 százalékát tette ki a fogyasztás. ${ }^{26}$ A beruházások hiánya mellett azt is hozzá kell tenni, hogy a világgazdaság ezen térségére is jellemző a túlzott fogyasztási hajlandóság az alacsony rendelkezésre álló jövedelmek ellenére, illetve ennek következményeként az alacsony megtakarítási hajlandóság. Mivel nagyobb a felhasználás, mint a belső termelés, a külkereskedelmi mérleg hiánya a folyó fizetési mérleg deficitjét eredményezi.

Mindezek fényében számíthatunk-e valódi felzárkózásra a Visegrádi Négyek további gazdasági fejlődése során? Ami Magyarországot illeti, néhány számítás elvégzése után kiderül, hogy az 1920 és 2016 közötti időszakban a hosszú távú éves növekedési ráta 1,77\%-ot tett ki. Utóbbi ráta egyfajta köztes állapotra utal a konvergencia és a divergencia között. A V4ek esetében közös sajátosság tehát a periféria jellegú földrajzi elhelyezkedés, a relatíve kisebb belső piac (Lengyelország kivételével), a magas fogyasztás és kedvező üzleti környezet fennállásakor beözönlő külföldi tőke, illetve az igen nagymértékű sérülékenység, externáliáknak való kitettség. A rendelkezésre álló adatok és a történelmi tapasztalat alapján arra a következtetésre juthatunk, hogy a térség konvergálásának megvalósítása a fejlett magországok teljesítményéhez csak igen szigorú fenntartások mellett válhat lehetségessé. Az exporttevékenység bővítése mellett óriási szükség lenne arra, hogy a képzett munkaerő valóban magas hozzáadott értékű termékek előállítására szakosodjon a jövőben. Ehhez viszont további beruházásokat kell végrehajtani mind a humántőke állomány további fejlesztése és hazai piacokon való megtartása, mind pedig a technológiai korszerűsítés

${ }^{26}$ LABAYE, 2013. 
érdekében. A V4 és KKE-ei országok másik potenciálja pedig nem más, mint a mezőgazdasági tevékenység felfuttatása. Utóbbi tényezőt a MacKinsey Global Institute is kiemelten kezelte 2013-as elemzésében. A humán és fizikai erőforrások, a növénytermesztési és állattenyésztési hagyományok, a kedvező elhelyezkedés és nyugati, illetve Unión kívül eső kelet-európai (orosz és ukrán) piacoktól való kellő távolság ideális feltételeket nyújthatna régiónknak, amely közép- és hosszú távon tovább bővíthetné az országok GDP-jét, illetve a válságot követő jelentős megtorpanás után ismét a felzárkózás útjára segítené a térséget.

Az elmúlt néhány évtizedben produkált eredmények tükrében az alábbi következtetés vonható le Kelet-Közép-Európa meghatározott országaival kapcsolatban. Az integrált periféria gazdaságok (például KKE-i országok, ezen belül a kutatás magját képező V4 térség) a napjainkra már történelmi teherré avanzsált aszimmetrikus interdependenciájuk (ide értve a külső finanszírozástól való óriási függést, a kisebb felvevőpiacot, alacsony nyersanyag-ellátottságot, az 1989 utáni rendszer-váltást megelőző jelentős gazdasági elmaradottság kumulálódását) következtében képtelenek a hosszú távú, centrumhoz való teljes felzárkózáshoz a globális kapitalizmus jelen viszonyai közepette. Kisebb volumenû és legtöbbször hektikus fejlődésük pedig inkább speciális esetnek minősülő epizódok láncolata, amely csak bizonyos - kezdeti előnyökkel - bíró gazdaságokban érhető tetten. Szigorúan gazdasági keretek között vizsgálódva pedig megállapítható, hogy Magyarország jelentôs divergenciát mutat a Visegrádi csoport többi tagjához viszonyítva a 2000-es évek közepe óta. Ezáltal az ország "különutas" fejlődési pályát jár be, amely további kétségeket támaszthat a gazdasági felzárkózás megvalósíthatósága tekintetében. Ezen felül, a Jánossy trendvonal elméletét követő számítás ${ }^{27}$ alapján megállapítható, hogy Magyarországon, közel 100 éves időintervallumra vetítve az egy főre eső reál GDP átlagos éves növekedési rátája közelítőleg 1.8 százalék, amely alapján nagyon hosszú távon sem nem konvergáló, sem pedig divergáló tendencia nem állapítható meg a legfejlettebb európai országokhoz képest.

27 SŐREG, 2018. 


\section{JEGYZET}

A tanulmányban bemutatottak a szerzô saját kutatási eredményei, amely kutatás az „EFOP-3.6.1-16-2016-00018 - A felsőoktatási rendszer K+F+I szerepvállalásának növelése intelligens szakosodás által Sopronban és Szombathelyen" címú projekt támogatásával valósult meg. / This article is based on the results of the author and was made in frame of the „EFOP3.6.1-16-2016-00018 - Improving the role of research+development+innovation in the higher education through institutional developments assisting intelligent specialization in Sopron and Szombathely".

\section{FELHASZNÁLT IRODALOM}

ANTALÓCZY KATALIN - SASS MAGDOLNA (2005): A külföldi működőtőkebefektetések regionális elhelyezkedése és gazdasági hatásai

Magyarországon. Közgazdasági Szemle, LII. évf., 2005. május (494-520. o.)

ARTNER ANNAMÁRIA. (2014). Tőke, munka, válság a globalizáció korában, Budapest: Akadémiai Kiadó Zrt., 312. o.

Carbonell, Jorge Bermejo - Werner, Richard A. (2018). Does

Foreign Direct Investment Generate Economic Growth? A New

Empirical Approach Applied to Spain. Economic Geography, 94:4, 425456. o. Elérhető:

https://www.tandfonline.com/doi/full/10.1080/00130095.2017.1393312\# aHR0cHM6Ly93d3cudGFuZGZvbmxpbmUuY29tL2RvaS9wZGYvMT AuMTA4MC8wMDEzMDA5NS4yMDE3LjEzOTMzMTI/bmVlZEFj Y2Vzcz10cnVlQEBAMADOI azonosító: https://doi.org/10.1080/00130095.2017.1393312

Curwin, Kevin D. - Mahutga, MatThew C. (2014): Foreign Direct

Investment and Economic Growth: New Evidence from Post-Socialist Transition Countries. Social Forces, Volume 92, Issue 3, March 2014, Pages 1159-1187. o. DOI azonosító: https://doi.org/10.1093/sf/sot128 Eurostat (2019), European Commission. Elérhető:

http://ec.europa.eu/eurostat

GÁL ZOLTÁN - SCHMIDT ANDREA. (2017): Geoeconomics in Central and Eastern Europe. Implications of FDI. In: Advances in Geoeconomics 
Növekedési lassulások és a függő piacgazdaságok elmélete Kelet-Közép-Európa esetében Magyarország gazdasági növekedése a Visegrádi Csoport fejlődési útja fényében

(szerk. Munoz J. M.). London; New York: Europa Economic Perspectives, 76-93. o. (Letöltve: 2019. június 29.)

GARRETT, GEOFFREY. (2004): Globalization's Missing Middle, Foreign Affairs, 83(6): 72-83. o. (Letöltve: 2019. június 29.)

Hall, Peter. A. - SoskiCe, DAvid (szerk.) (2001): Varieties of Capitalism, The Institutional Foundations of Comparative Advantage. Oxford:

Oxford University Press, 540. o.

INTERNATIONAL VISEGRAD FUND (2018): A visegrádi csoport története.

Elérhetô: http://www.visegradgroup.eu/tortenelem

LABAYE, ERIC et al. (2013), A new dawn: Reigniting growth in Central and

Eastern Europe, McKinsey Global Institute, 84. o. Elérhető:

https://www.mckinsey.com/ / media/McKinsey/Global\%20Themes/Eur ope $/ \mathrm{A} \% 20$ new $\% 20$ dawn $\% 20$ Reigniting $\% 20$ growth $\% 20$ in $\% 20$ Central $\%^{2}$ 20and \%20Eastern\%20Europe/MGI CEE A new dawn Full report Dec 2013.ashx

NÖlKE, ANDREAS.-VliegEnTHART, ARJAN. (2009): Enlarging the Varieties of Capitalism. The Emergence of Dependent Market Economies in East Central Europe, World Politics, 61(4): 670-702. o. (Letöltve: 2019. június 19.). DOI azonosító: https://doi.org/10.1017/S0043887109990098

RAPACKI, RYSZARD. - PRÓCHNIAK, MARIUSZ. (2009), The EU Enlargement and Economic Growth in the CEE New Member Countries. Economic Papers 367, 1-21. o. Elérhető:

http://ec.europa.eu/economy finance/publications/pages/publication1 4295 en.pdf DOI azonosító: DOI 10.2765/23063

SimiOnESCU, MiHAELA. et al. (2017): Determinants of Economic Growth in V4 Countries and Romania. Journal of Competitiveness, Vol. 9, Issue 1, 103-116. o. (Letöltve: 2019. június 19.). DOI azonosító:

https://doi.org/10.7441/joc.2017.01.07

Söreg, Krisztina (2018): Long-Term Growth Dynamics of Emerging Economies in Light of Jánossy's Trendline Theory. PEOPLE:

International Journal of Social Sciences, $4: 1,571-590$. o. (Letöltve: 2019. június 21.). DOI azonosító: https://dx.doi.org/10.20319/pijss.2018.41.571590

The Fraser Institute (2018): Economic Freedom. Elérhető: https://www.fraserinstitute.org/studies/economic-freedom

The Maddison-Project Database (2019): „The Maddison-Project”. Elérhető: http://www.ggdc.net/maddison/maddison-project/data.htm 
The World Bank (2019): World Development Indicators. Elérhető: http://databank.worldbank.org/data/reports.aspx?source $=$ worlddevelopment-indicators

United Nations Conference on Trade and Development (2019):

UNCTADstat. Elérhetô:

http://unctadstat.unctad.org/wds/TableViewer/tableView.aspx 